\title{
PENGARUH PENYULUHAN METODE FAST TERHADAP PENGETAHUAN PERAWAT DALAM DETEKSI DINI PENYAKIT STROKE DI RSUD H.A SULTHAN DAENG RADJA KABUPATEN BULUKUMBA
}

\author{
Nadia Alfira \\ STIKES Panrita Husada Bulukumba \\ Alamat korespondensi : (karuajune9891@gmail.com/085299239921)
}

\begin{abstract}
ABSTRAK
Pengetahuan mengenai keluhan stroke, terutama pada kelompok risiko tinggi (hipertensi, atrial fibrilasi, kejadian vaskular lain dan diabetes) perlu di sebarluaskan. Untuk mengetahui dan mendeteksi terjadinya stroke, kita dapat menggunakan metode $F-A-S-T$. Tujuan penelitian ini adalah diketahuinya ada pengaruh penyuluhan metode FAST terhadap pengetahuan perawat dalam deteksi dini penyakit stroke di Rsud H.A Sulthan Daeng Radja Kabupaten Bulukumba. Populasi dalam penelitianini adalah perawat di Rsud H.A Sulthan Daeng Radja Kabupaten Bulukumba di ruangan Plamboyan dan Seruni sebanyak 41 orang. sampel dalam penelitian ini seluruh populasi di jadikan sampel sebanyak 41 orang. teknik sampling yang di gunakan adalah total sampling. Penelitian ini adalah penelitian kuantitatif dengan menggunakan pre-experimental design. Jenis uji yang di gunakan adalah uji Wilcoxon dengan hasil penelitian yaitu pada pre test, jumlah pengetahuan perawat kategori kurang sebanyak 29 responden $(70,7 \%)$ dan kategori baik sebanyak 3 responden $(7,3 \%)$ sedangkan pad apost test, jumlah pengetahuan perawat kategori cukup sebanyak 17 responden $(41,54 \%)$ dan kategori baik sebanyak 9 responden $(22 \%)$.Kesimpulan dari penelitian ini yaitu. Terdapat Pengaruh Penyuluhan Metode FAST Terhadap Pengetahuan Perawat Dalam Deteksi Dini Penyakit Stroke di RSUD H. Andi Sulthan Daeng Radja Kabupaten Bulukumbadengan nilai $P=$ 0,000 . adapun saran dalam penelitian ini yaitu Hasil penelitian ini dapat menambah referensi perpustakaan dan wawasan mahasiswa Stikes, menambah informasi dan masukan bagi petugas kesehatan untuk meningkatkan kualitas pelayanan kesehatan,,di harapkan dapat dilakukan penelitian lanjutan.
\end{abstract}

\section{Kata Kunci : Metode FAST, Pengetahuan Perawat, Penyakit Stroke}

\section{PENDAHULUAN}

Stroke merupakan masalah kesehatan utama di masyarakat karena penyebab, kecacatan serta penyebab menurunnya kualitas hidup yang memiliki karakteristik tanda dan gejala neurologis yang berkembang dengan cepat, dengan gejala yang berlangsung lebih dari 24 jam atau menimbulkan kematian (Tanto,Liwang \& Hanifati 2014).

World Health organization (WHO) 2013, Terdapat sekitar 15 juta orang menderita stroke setiap tahun, diantaranya ditemukan jumlahkematian sebanyak 5 juta orang dan yang mengalami kecacatan permanen diperkirakan terdapat 795.000 penderita stroke dengan 600.000 penderita serangan pertama dan 185.000 adalah serangan berulang dengan angka kematian 150.000 (AHA, 2014).Yayasan Stroke Indonesia (Yastroki) menyatakan Jumlah penderita stroke di Indonesia diperkirakan 2.137.941 (12,1\%) orang.Kejadian stroke di Indonesia terbesar berada di Provinsi Sulawesi Selatan yaitu sekitar $(17,9 \%)$ sedangkan yang terendah berada di Provinsi Papua Barat (5,3\%).
Mengenal gejala stroke dan perawatan darurat sangat penting bagi masyarakat luas dan petugas kesehatan profesional Tenaga medis atau dokter terlibat di unit gawat darurat atau pada fasilitas prahospital harus mengerti tentang gejala stroke akut dan penanganan pertama yang cepat dan benar. Pendidikan berkesinambungan perlu dilakukan terhadap masyarakat tentang pengenalan atau deteksi stroke. Pada setiap kesempatan, pengetahuan mengenai keluhan stroke, terutama pada kelompok risiko tinggi (hipertensi, atrial fibrilasi, kejadian vaskular lain dan diabetes) perlu disebarluaskan. Untuk mengetahui dan mendeteksi terjadinya stroke, kita dapat menggunakan metode $F-A-S-T$ (facial movement, arm movement, speech, dan time to call) (Yueniwati, 2014).

Berdasarkan data di dapat dari peneliti RSUD $H$. Andi Sulthan Daeng Radja Bulukumba didapatkan jumlah pasien stroke tahun 2015 sebanyak 965 pasien, tahun 2016 sebanyak 1226 pasien, pada tahun 2017 sebanyak 1220 pasien sedangkan pada tahun 2018 pada bulan Januari sebanyak 48 pasien stroke, bulan Februari sebanyak 52 pasien 
stroke. Berdasarkan dari datayang di dapatkan jumlah perawat di ruangan Flamboyan sebanyak 21 perawat dan Seruni sebanyak 20 perawat serta dari hasil wawancara langsung tenaga perawat yang bertugas di bagian perawatan Flamboyan dan Seruni yang terdiri dari 4 perawat mengatakan sebagian besar belum memahami konsep dan penerapan deteksi dini pencegahan stroke dengan metode FAST (face movement, arm movement, speech, time).

Berdasarkan fakta diatas, maka penulis tertarik peneliti "pengaruh penyuluhan metode FAST terhadap pengetahuan perawat dalam deteksi dini penyakit stroke di RSUD $\mathrm{H}$. Andi Sulthan Daeng Radja Bulukumba".

\section{BAHAN DAN METODE}

Lokasi, Populasi, Sampel

Penelitian ini dilaksanakan di Ruangan Seruni \& Ruangan Flamboyan RSUD H. Andi Sulthan Dg. Radja Bulukumba pada November 2018. Populasi dalam penelitian ini adalah 41 orang perawat. Teknik pengambilan sampel pada penelitian ini adalah dengan cara total sampling, artinya semua populasi di jadikan sampel dalam penelitian ini dengan kriteria tertentu yang telah di tetapkan dalam penelitian. Sampel dalam penelitian ini adalah berjumlah 41 responden.

Pengumpulan Data

Instrumen penelitian merupakan pedoman penelitian yang digunakan oleh peneliti secara tertulis berupa pedoman wawancara, pengamatan, dan daftar pertanyaan yang disiapkan oleh peneliti untuk mendapatkan informasi dari responden (Nursalam, 2011). Yaitu instrument yang di gunakan dalam penelitian ini adalah lembar kousioner yang berupa multipelchoice dan liflet yang merupakan cara pengimpulan data dan mengadakan pengamatan secara langsung kepada responden penelitian untuk mencari perubahan atau hal - hal yang akan di teliti.

\section{Pengolahan Data}

\section{Editing}

Editing adalah tahapan kegiatan memeriksa validitas data yang masuk seperti memeriksa kelengkapan pengisian kuesioner, kejelasan jawaban, relevansi jawaban dan keseragaman suatu pengukuran.

2. Coding

Coding adalah tahapan kegiatan mengklasifikasi data dan jawaban menurut kategori masing-masing sehingga memudahkan dalam pengelompokan data.

\section{Processing}

Processing adalah tahapan kegiatan memproses data agar dapat dianalisis. Pemrosesan data dilakukan dengan cara memasukkan data hasil pengisian kuesioner ke dalam master tabel.

4. Cleaning

Cleaning yaitu tahapan kegiatan pengecekan kembali data yang sudah di masukkandan melakukan koreksi bila terdapat kesalahan. (Nursalam, 2016)

\section{Analisis Data}

1. Analisis Univariat

Digunakan untuk mendeskripsikan variabel penelitian guna memperoleh gambaran atau karakteristik sebelum dilakukan analisi bivariat. Hasil dari penelitian ditampilkan dalam bentuk distribusi frekuensi.

2. Analisis Bivariat

Analisis Bivariat, Uji Bivariat di lakukan untuk mencari hubungan atau pengaruh antara variable independen dan variable dependen dengan uji yang di gunakan adalah uji Wilcoxon bila memenuhi syarat $\alpha=0,05$ dan melihat resiko nilai relative $(R R)$.

\section{HASIL PENELITIAN}

1. Analisis Univariat

Tabel 1 Distribusi Jumlah Responden Berdasarkan Karakteristik Respondendi RSUD H. Andi Sulthan Daeng Radja Kabupaten Bulukumba. $(n=41$

\begin{tabular}{|l|c|c|}
\hline \multicolumn{1}{|c|}{ Karakteristik } & $\mathrm{n}$ & $\%$ \\
\hline $\begin{array}{l}\text { Jenis kelamin } \\
\text { Laki-Laki }\end{array}$ & 10 & 24.4 \\
Perempuan & 31 & 75.6 \\
\hline Umur & & \\
$\quad<30$ tahun & 26 & 63.4 \\
$\quad \geq 30$ tahun & 15 & 36.6 \\
\hline Pendidikan & & \\
$\quad$ DIllkeperawatan & 18 & 43.9 \\
S1Keperawatan +Ners & 23 & 56.1 \\
\hline Lama Kerja & & \\
$\quad$ <5 Tahun & 30 & 73.2 \\
$\quad$ 55 Tahun & 11 & 26.8 \\
\hline Status Kepegawaian & & \\
$\quad$ PNS & 10 & 24.4 \\
Honorer & 31 & 75.6 \\
\hline
\end{tabular}

Dari tabel 1 menunjukkan responden yang jenis kelamin yang paling banyak adalah berjenis kelamin perempuan, yaitu dengan jumlah 31 orang $(75,6 \%)$, dan jenis kelamin laki-laki yaitu berjumlah 10 orang $(24,4 \%)$. dari 41 responden lebih banyak responden yang berada pada rentang usia $<30$ tahun tahun, yaitu sebanyak 26 orang $(63,4 \%)$, yang berusia antara $\geq 30$ tahun 
yaitu sebanyak 15 orang (36,6\%) Berdasarkan pendidikan Responden paling banyak memiliki pendidikan S1 Keperawatan + Ners yang berjumlah 23 orang $(56,1 \%)$, dan yang memiliki pendidikan DIII keperawatan berjumlah 18 orang (43.9\%). Berdasarkan Lama kerja yaitu paling banyak yang bekerja $<5$ Tahun yaitu 30 orang $(73,2 \%)$ dan yang bekerja $\geq 5$ Tahun ada 11 orang $(26,8 \%)$. Berdasarkan status kepegawaian lebih banyak yang berstatus honorer 31 orang $(75,6 \%)$ sedangkan yang berstatus PNS ada 10 orang $(24,4 \%)$.

2. Analisis Bivariat

Tabel 2 Distribusi Jumlah Responden Berdasarkan tingkat pengetahuan perawat tentang deteksi dini penyakit stroke sebelum dan sesudah dilakukan penyuluhan tentang metode FAST di RSUD H. Andi Sulthan Daeng Radja Kabupaten Bulukumba

\begin{tabular}{|c|c|c|c|c|}
\hline \multirow{2}{*}{ Pengetahuan } & \multicolumn{3}{|c|}{ Kepatuhan Berobat } \\
\cline { 2 - 5 } & \multicolumn{2}{|c|}{ Pretst } & \multicolumn{2}{c|}{ Posttest } \\
\cline { 2 - 5 } & $F$ & $\%$ & $F$ & $\%$ \\
\hline Kurang & 29 & 70.7 & 15 & 36.6 \\
\hline Cukup & 9 & 22.0 & 17 & 41.5 \\
\hline Baik & 3 & 7.3 & 9 & 22.0 \\
\hline Jumlah & 41 & 100.0 & 41 & 100.0 \\
\hline
\end{tabular}

Berdasarkan tabel 2, diketahui dari jumlah 41 responden yang dinilai pretest tingkat pengetahuan lebih banyak responden dengan dengan pengetahuan kurang yaitu sebanyak 29 orang $(70,7 \%)$, dengan pengetahuan cukup 9 orang $(22,0 \%)$ sedangkan dengan pengetahuan baik 3 orang $(7,3 \%)$. Berbeda dengan posttest tingkat pengetahuan lebih banyak responden dengan tingkat pengetahuan cukup yaitu 17 responden (41,5\%), dengan pengetahuan kurang ada 15 orang $(36,6 \%)$, sedangkan dengan pengetahuan baik ada 9 orang $(22,0 \%)$

Tabel 3 Pengaruh Pengetahuan Perawat Tentang Deteksi Dini Penyakit Stroke sebelum dan setelah Penyuluhan Metode FAST di RSUD H. Andi Sulthan Daeng Radja Kabupaten Bulukumba

\begin{tabular}{|c|c|c|c|c|}
\hline & $\mathrm{n}$ & $\begin{array}{c}\text { Median } \\
\text { (minimum- } \\
\text { maksimum }\end{array}$ & Rerata & $P$ \\
\hline $\begin{array}{c}\text { Pengetahuan } \\
\text { sebelum } \\
\text { penyuluhan }\end{array}$ & 41 & $10(5-16)$ & $\begin{array}{c}9.90 \pm \\
2.91\end{array}$ & \\
\hline $\begin{array}{c}\text { Pengetahuan } \\
\text { setelah } \\
\text { penyuluhan }\end{array}$ & 41 & $12(8-17)$ & $\begin{array}{c}12.6 \pm \\
2.63\end{array}$ & \\
\hline
\end{tabular}

Berdasarkan tabel 2, diketahui tingkat pengetahuan sebelum penyuluhan dari jumlah 41 responden didapatkan nilai median (maksimum-minumum) yaitu 10 (516) dengan rerata $9.90 \pm 2.91$. sedangkan tingkat pengetahuan setelah penyuluhan dari jumlah 41 responden didapatkan nilai median (maksimum-minumum) yaitu 12 (817) dengan rerata $12.6 \pm 2.63$

Setelah dilakukan analisis menggunakan uji Chi Square, diperoleh pvalue sebesar $0.000<\alpha 0.05$, dengan demikian dalam penelitian ini diterima, dan dapat dinyatakan ada pengaruh pengetahuan penyuluhan metode FAST terhadap pengetahuan perawat dalam deteksi dini penyakit stroke di RSUD H. Andi Sulthan Daeng Radja Kabupaten Bulukumba

\section{PEMBAHASAN}

Pada hasil penelitian ini tingkat pengetahuan responden sebelum diberikan penyuluhan (pre test) dari 41 jumlah responden paling banyak responden pada tingkat pengetahuan perawat kategori kurang sebanyak 29 responden (70,7\%). Sedangkan tingkat pengetahuan perawat paling sedikit pada kategori Baik sebanyak 3 responden $(7,3 \%)$.

Hasil penelitian ini sejalan pula dengan penelitian yang dilakukan oleh Haryono (2013) Tingkat pengetahuan responden sebelum diberikan pendidikan kesehatan (pre test) menunjukkan sebagian besar responden pada kelompok perlakuan memiliki pengetahuan cukup yaitu sebanyak 28 responden $(70 \%)$, pengetahuan baik 10 responden (25\%), sedangkan responden dengan pengetahuan buruk sebanyak 2 responden (5\%). Soekanto (2002) (dikutip dalam Lestari, 2015) menjelaskan bahwa tingkat pengetahuan (knowledge) adalah kemampuan seseorang tentang sesuatu. Berdasarkan definisi tersebut diatas dapat disimpulkan bahwa pengetahuan adalah suatu proses mengingat dan mengenal kembali obyek yang telah dipelajari melalui panca indera pada suatu bidang tertentu secara baik.

Sedangkan hasil penelitian tingkat pengetahuan responden setelah diberikan penyuluhan (post test) dari 41 jumlah responden paling banyak responden pada tingkat pengetahuan perawat kategori cukup sebanyak 17 responden (41,5\%). Sedangkan tingkat pengetahuan perawat paling sedikit pada kategori Baik sebanyak 9 responden (22,0\%).

Berdasarkan hasil analisis dengan menggunakan uji Wilcoxon diperoleh nilai 
significancy sebesar 0,000 di bandingkan dengan nilai $p<0,05$, maka dapat disimpulkan bahwa "terdapat Pengaruh Penyuluhan Metode FAST Terhadap Pengetahuan Perawat dalam Deteksi Dini Penyakit Stroke di RSUD H. Andi Sulthan Daeng Radja Kabupaten Bulukumba".

Hasil penelitian ini sejalan dengan penelitian yang dilakukan oleh Aris (2013), berdasarkan hasil analisis didapatkan terdapat perbedaan pengetahuan antara kelompok yang diberikan pelatihan dan yang tidak diberikan pelatihan, pengetahuan pada kelompok yang diberikan pelatihan lebih tinggi dibandingkan dengan kelompok yang tidak diberikan pelatihan. Selain itu juga terdapat beda mean yang secara statistic signifikan antara kelompok pengetahuan yang diberi pelatihan dan tanpa diberikan pelatihan.Hasil penelitian sejalan pula dengan penelitian yang dilakukan oleh Murtiningsih (2016) Terdapat perbedaan tingkat pengetahuan deteksi dini pada stroke pada kelompok perlakuan sebelum dan sesudah menerima pendidikan kesehatan dengan nilai $(p=0,003)$, Nilai $p<0,05$ dapat disimpulkan ada pengaruh pendidikan kesehatan FAST terhadap pengetahuan tentang deteksi dini pada stroke di Desa Sambirejo Kecamatan Plupuh Sragen.

\section{KESIMPULAN}

1. Tingkat pengetahuan perawat dalam deteksi dini sebelum penyuluhan kesehatan paling banyak responden pada tingkat pengetahuan perawat kategori kurang sedangkan Tingkat pengetahuan perawat tentang deteksi dini setelah penyuluhan kesehatan paling banyak responden pada tingkat pengetahuan perawat kategori cukup.

2. Dari hasil analisis dengan mengunakan uji Wilcoxon, Terdapat pengaruh penyuluhan metode FAST terhadap pengetahuan perawat dalam deteksi dini penyakit stroke di RSUD H. Andi Sulthan Daeng Radja Kabupaten Bulukumba.

\section{SARAN}

Hasil penelitian ini dapat menambah referensi perpustakaan dan wawasan mahasiswa, Dapat menambah informasi dan masukan bagi petugas kesehatan agar dapat meningkatkan kualitas pelayanan kesehatan, Bagi penelitian keperawatan diharapkan dapat dilakukan penelitian lanjutan mengenai pengaruh penyuluhan metode fast terhadap pengetahuan perawat dalam deteksi dini penyakit stroke.

\section{DAFTAR PUSTAKA}

Lestari, T. (2015). Kumpulan Teori Untuk Kajian Pustaka Penelitian Kesehatan, Nuha Medika: Sorowajan Baru, Yogyakarta

Nursalam, (2011). Metodologi Penelitian Ilmu Keperawatan Pendekatan Praktis. Salemba Medika: Jakarta

Nursalam, (2016). Metodologi Penelitian Ilmu Keperawatan Pendekatan Praktis. Salemba Medika: Jakarta

Tanto, Chris. et. Al, (2014). Kapita selekta Kedokteran, Edisi ke-4. Jakarta : Media Aesculapius.

Yueniwati, Yuyun. (2014). Deteksi dini stroke iskemia dengan pemeriksaan ultrasonografi vascular dan variasi genetika. Malang: UB-Press. 